\title{
Measles surveillance in Canada, 2019
}

\author{
Cameron Coulby', Francesca Reyes Domingo', Joanne Hiebert', Susan G Squires*
}

\begin{abstract}
Background: The Public Health Agency of Canada (PHAC) has conducted enhanced measles surveillance since 1998, the year endemic measles transmission was eliminated in Canada. The objective of this annual national measles surveillance report is to provide an epidemiologic summary of measles activity reported in Canada for 2019 in order to provide evidence to support the continued verification of Canada's measles elimination status.
\end{abstract}

Methods: Measles surveillance data are housed in the Canadian Measles and Rubella Surveillance System (CMRSS) database. Descriptive analyses of demographics and risk factors were performed. Outbreak characteristics were summarized and genotypic analyses conducted. Surveillance, laboratory and vaccine coverage data for 2019 were used to assess Canada's status against the Pan American Health Organization (PAHO) essential criteria for the verification of measles elimination.

Results: In 2019, 113 measles cases were reported in Canada (crude incidence rate of 3.0 cases per 1,000,000 population). Of these cases, 42 (37\%) were imported into Canada, and of the imported cases, $12(29 \%)$ resulted in further transmission. Infants younger than one year had the highest age-specific incidence rate at 13.1 cases per $1,000,000$ population. Only $29 \%$ of cases had one or more documented doses of measles-containing vaccine. One-fifth (19\%) of cases were hospitalized; no deaths were reported. Genotype information was available for $100 \%$ of outbreaks reported in 2019 and $90 \%$ of non-outbreak-related measles cases; of cases with genotype information available, $27 \%$ were B3 and $73 \%$ were D8.

Conclusion: Despite meeting/partially meeting only three out of four of PAHO's essential criteria for measles elimination status, there is no evidence that endemic measles transmission has been reestablished in Canada.
This work is licensed under a Creative Commons Attribution 4.0 International License.

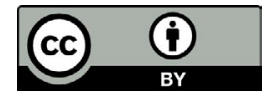

Affiliations

${ }^{1}$ Centre for Immunization and Respiratory Infectious Diseases, Public Health Agency of Canada, Ottawa, ON

2 National Microbiology Laboratory, Public Health Agency of Canada, Winnipeg, MB

*Correspondence:

phac.vpd-mev.aspc@canada.ca

Suggested citation: Coulby C, Reyes Domingo F, Hiebert J, Squires SG. Measles surveillance in Canada, 2019. Can Commun Dis Rep 2021;47(3):149-60. https://doi.org/10.14745/ccdr.v47i03a05

Keywords: measles, travel health, surveillance, measles elimination, vaccination

\section{Introduction}

Although vaccine preventable, measles is still a major cause of morbidity and mortality, especially in children younger than five years (1). In 2018, the last year for which estimates are available, there were approximately 9.8 million measles cases and 142,000 measles-related deaths worldwide (2). Global efforts to eliminate measles (which is defined as the absence of endemic measles transmission for at least 12 months in a defined geographic area with a well-performing surveillance system) began in 1963 with the introduction of the first measles vaccine $(1,3)$.

In 1998, Canada was one of the first countries to eliminate endemic measles transmission following the pan-Canadian introduction of routine two-dose measles-mumps-rubella (MMR) vaccination for children in 1996-1997 (3,4). However, Canada's elimination status is threatened by infected travellers importing measles into Canada, particularly into pockets of the Canadian population that have suboptimal measles vaccination coverage rates (3-5). As such, it is critical that Canada has a strong measles surveillance capacity, including laboratory capacity, to rapidly identify measles cases so that public health actions can be taken to reduce spread and prevent the reestablishment of endemic measles (6).

The Public Health Agency of Canada (PHAC), including the National Microbiology Laboratory (NML), works with provinces and territories to conduct national measles surveillance. The Agency reports on measles activity weekly both publicly on the canada.ca website and to the Pan American Health Organization (PAHO) $(7,8)$. 
The objective of this annual national measles surveillance report is to provide an epidemiologic summary of measles activity reported in Canada for 2019 in order to provide evidence to support the continued verification of measles elimination status.

\section{Methods}

\section{Surveillance data}

The Canadian Measles and Rubella Surveillance System (CMRSS) is an active, enhanced surveillance system supported by all Canadian provinces and territories. Confirmed cases of measles meeting the national case definition were reported weekly to PHAC by provinces and territories and housed in the CMRSS database $(7,8)$. All confirmed cases of measles with rash onset between January 1, 2019, and December 31, 2019, were included in this report. PHAC assigns epidemiologic weeks of rash onset with week one ending on the first Saturday of the year. A data validation process was conducted with all provinces and territories; this process included querying for missing data, identifying incorrect entries and confirming values with reporting jurisdictions. Cases with missing data were included in the analysis as appropriate. Visitors to Canada who were diagnosed with measles during their stay were included in this analysis.

A case was considered to have received a dose of measles-containing vaccine if the date of the vaccination is documented; otherwise, the case was considered unvaccinated. Cases with an unknown vaccination history were considered unvaccinated. A case was considered to be hospitalized if admitted to hospital due to measles or due to measles-related complications, but not if they were only seen in the emergency department.

The reporting province or territory identified the source of exposure in the course of the public health investigation. The sources of exposure were classified as outside Canada (imported); within Canada and linked to an imported case (import-related); within Canada and linked to a case of unknown origin; or unknown source/sporadic.

\section{Verification of measles elimination through national and international goals and targets}

PAHO set out four criteria for the ongoing verification of measles elimination (9), (Table 1). The indicators, established by PAHO, of a well-performing surveillance system are based on investigation of measles-like illness (i.e. suspected cases), whereas only confirmed cases are nationally notifiable in Canada. As such, these data can only indirectly address the PAHO criteria.

\section{Genotyping}

NML routinely performs virus genotyping of all reverse transcription polymerase chain reaction (RT-PCR) confirmed cases for which viral specimens (respiratory swabs and/or urine) are available. The terminal 450 nucleotides of the measles
Table 1: Pan American Health Organization essential criteria for the verification of measles elimination

\begin{tabular}{|l|l|}
\hline \multicolumn{1}{|c|}{ Criterion } & \multicolumn{1}{c|}{ Indicator } \\
\hline $\begin{array}{l}\text { Verify the interruption of endemic } \\
\text { measles cases for a period of at least } \\
3 \text { years from the last known endemic } \\
\text { case, in the presence of high-quality } \\
\text { surveillance }\end{array}$ & $\begin{array}{l}\text { Zero cases of endemic } \\
\text { transmission }\end{array}$ \\
\hline $\begin{array}{l}\text { Maintain high-quality surveillance } \\
\text { sensitive enough to detect imported } \\
\text { and import-related cases }\end{array}$ & $\begin{array}{l}\text { >2 suspect cases per 100,000 } \\
\text { population adequately } \\
\text { investigated }\end{array}$ \\
\hline $\begin{array}{l}\text { Verify the absence of endemic } \\
\text { measles virus strains through viral } \\
\text { surveillance }\end{array}$ & $\begin{array}{l}\text { Measles genotype assessed in } \\
80 \% \text { of outbreaks }\end{array}$ \\
\hline $\begin{array}{l}\text { Verify adequate immunization in the } \\
\text { population }\end{array}$ & $\begin{array}{l}\text { 95\% of population cohorts } \\
\text { aged 1-40 years have } \\
\text { received a measles-containing } \\
\text { vaccine }\end{array}$ \\
\hline
\end{tabular}

nucleoprotein $(\mathrm{N})$ gene (the $\mathrm{N}-450$ ) were sequenced in accordance with World Health Organization (WHO) guidelines $(10,11)$. Sequences were aligned with WHO genotype reference sequences and maximum parsimony phylogenetic trees generated in MEGA X software (12). Measles viral sequences were deposited in the WHO Measles Nucleotide Surveillance (MeaNS) database and distinct sequence identifiers (IDs) acquired. Sequences were also compared to designated named strains and to sequences deposited by other members of the global measles laboratory network $(11,13)$. All confirmed cases of measles with rash onset between January 1, 2019, and December 31, 2019, that had been genotyped were included in this report $(n=73)$. The sequences were deposited in GenBank, the National Institutes of Health (NIH) genetic sequence database, with accession numbers MT386938 to MT387010.

\section{Analysis}

Descriptive epidemiologic analyses were performed based on the available variables in the CMRSS database, including age, sex, location, onset date, vaccination, hospitalization, source of exposure and genotype (8). Statistical comparisons between frequencies were completed using Mid-P exact test, as appropriate. Measles outbreaks, defined as two or more confirmed cases linked epidemiologically, virologically or both, were described based on available information (14). Incidence rates were calculated using Statistics Canada population estimates for July 1, 2019.

\section{Results}

A total of 113 confirmed measles cases (incidence rate of 3.0 cases per 1,000,000 population) were reported from seven provinces and one territory, in 2019 (Figure 1). Approximately one-third of these cases were related to one outbreak in the province of Québec. Of the 113 total confirmed cases, 73 (65\%) were genotyped. The genotypes detected were B3 $(n=20)$ and D8 $(n=53)$, both of which circulated globally in 2019, based on data submitted to the WHO MeaNS database (15). Altogether, 
Figure 1: Number of reported measles cases $(\mathrm{N}=113)$, by epidemiologic week of rash onset and reporting province or territory, Canada, 2019

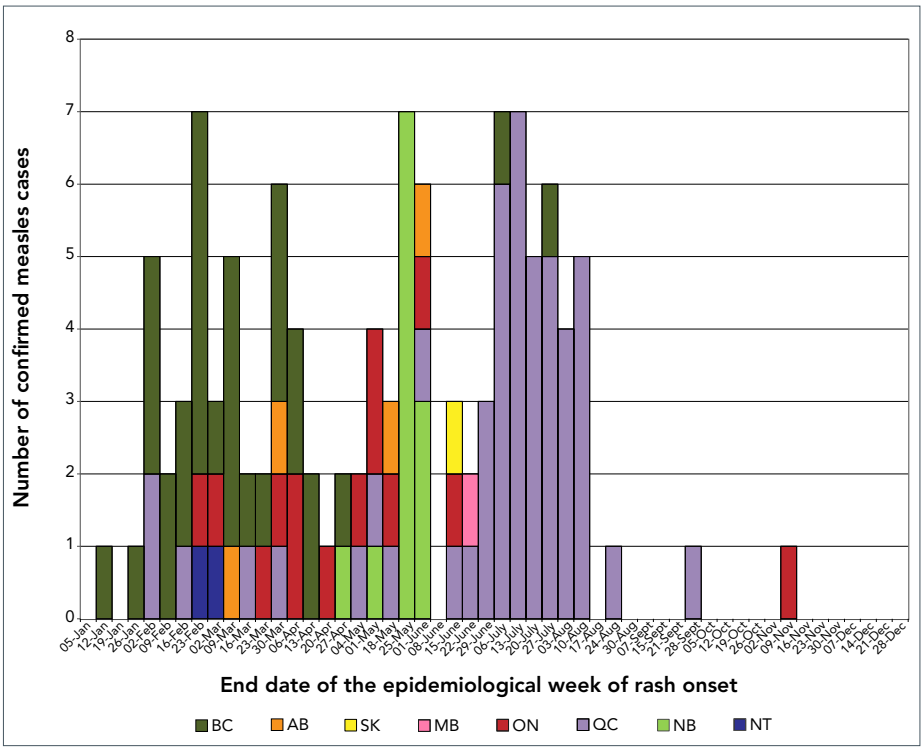

Abbreviations: AB, Alberta; BC, British Columbia; MB, Manitoba; NB, New Brunswick; NT, Northern Territories; ON, Ontario; OC, Québec; SK, Saskatchewan

102 cases were laboratory-confirmed and 11 cases were epidemiologically linked to a laboratory-confirmed case.

Information on age, sex and province or territory of residence was complete for all measles cases reported in 2019. The cases were aged from younger than one year to 73 years, with a median age of 15 years. Cases were most often in the 5-14 year age group $(29 \%, n=33)$ or the $25-44$ year age group $(25 \%$, $\mathrm{n}=28$ ). The incidence rate of measles declined across age groups, with the highest incidence rate reported in infants younger than one year (13.1 cases per 1,000,000 population) and the lowest in adults 65 years and older $(0.15$ cases per $1,000,000$ population; Figure 2). The majority of cases $(65 \%, n=73)$ were male.

\section{Vaccination}

Of the 113 measles cases reported in Canada in 2019, 71\% $(n=80)$ had no documented doses of measles-containing vaccine; of these, 16 cases had an unknown vaccination history. Over 40\% of the unvaccinated measles cases $(n=34)$ were related to an outbreak in a non-vaccinating community (see Outbreaks section,
Figure 2: Confirmed measles cases $(\mathrm{N}=113)$ and incidence rates (per 1,000,000 population) by age group and vaccination status, Canada, 2019

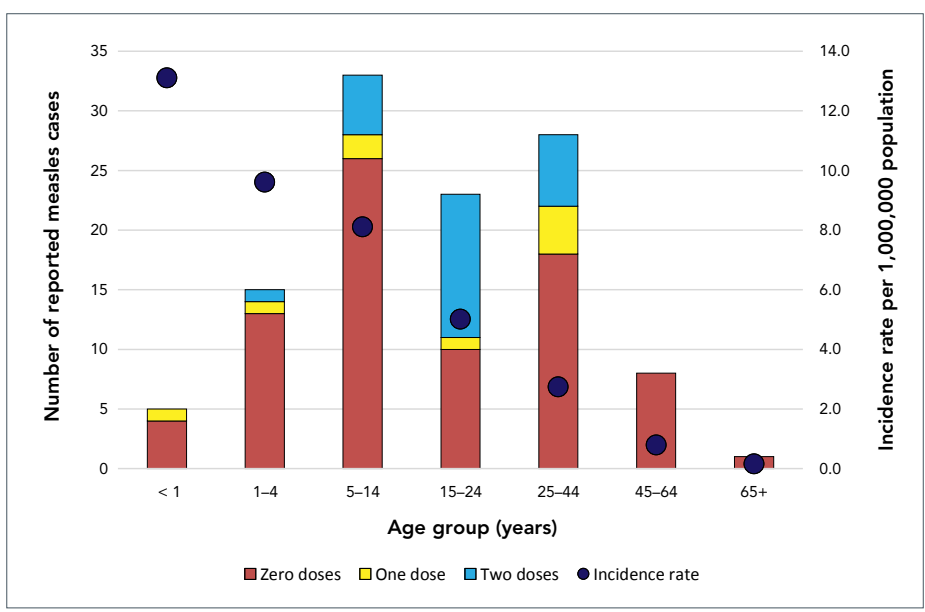

below). Of note, 57\% ( $n=13)$ of cases in the 15-24 year age group had at least one documented dose of measles-containing vaccine; this is significantly higher than the proportion of cases with at least one dose of documented measles-containing vaccine in any other age group ( $p<0.01$; Figure 2$)$.

\section{Hospitalization}

All 113 measles cases reported had hospitalization information complete. In total, $19 \%$ of cases $(n=21)$ were hospitalized, resulting in a hospitalization rate of 0.6 per $1,000,000$ population. The mean age of hospitalized cases was 31 years (median: 34 years, range: $1-73$ years). On average, hospitalized cases were significantly older than non-hospitalized cases $(p<0.001)$. Of the 21 hospitalized cases, only three (14\%) had any documented doses of measles vaccination.

\section{Molecular epidemiology by source of exposure} Of the 113 confirmed cases of measles in 2019, 42 (37\%) were imported into Canada after exposure to measles during travel (Table 2). Twelve of these imported cases transmitted measles within Canada, which resulted in an additional 60 import-related cases (Table 3). In total, imported and import-related cases accounted for $90 \%(n=102)$ of the total cases, while $10 \%(n=11)$ had an unknown or sporadic source of measles exposure (Table 2, Table 3).

Table 2: Summary of imported measles cases by source of exposure $(n=42)$ and by genotype, 2019

\begin{tabular}{|c|c|c|c|c|}
\hline $\begin{array}{c}\text { WHO } \\
\text { region } \\
\text { (number of } \\
\text { cases) }\end{array}$ & Country & $\begin{array}{l}\text { Number } \\
\text { of cases }\end{array}$ & $\begin{array}{l}\text { Genotype } \\
\text { (number } \\
\text { of cases) }\end{array}$ & $\begin{array}{l}\text { WHO-named strain, if applicable, MeaNS Distinct Sequence ID } \\
\text { (Number of cases) }\end{array}$ \\
\hline \multirow{4}{*}{$\begin{array}{l}\text { Western } \\
\text { Pacific } \\
(n=25)\end{array}$} & Philippines & 11 & B3 $(n=11)$ & $\begin{array}{l}\text { MVi/Marikina City.PHL/10.18/, } 5306(n=4) ; N / A, 6018(n=2) ; \text { MVi/Gombak.MYS/40.15/, } \\
4274(n=1) ; N / A, 5654(n=1) ; N / A, 5793(n=1) ; N / A, 5904(n=1) ; N / A, 6083(n=1)\end{array}$ \\
\hline & Viet Nam & 11 & $\mathrm{D} 8(\mathrm{n}=6)$ & MVs/Gir Somnath.IND/42.16/, $4683(n=3) ; N / A, 5840(n=2) ; N / A, 5823(n=1)$ \\
\hline & Cambodia & 1 & $D 8(n=1)$ & MVs/Gir Somnath.IND/42.16/, $4683(n=1)$ \\
\hline & $\begin{array}{l}\text { Multiple } \\
\text { countries }\end{array}$ & 2 & $D 8(n=1)$ & MVs/Gir Somnath.IND/42.16/, $4683(n=1)$ \\
\hline
\end{tabular}


Table 2: Summary of imported measles cases by source of exposure $(n=42)$ and by genotype, 2019 (continued)

\begin{tabular}{|c|c|c|c|c|}
\hline $\begin{array}{c}\text { WHO } \\
\text { region } \\
\text { (number of } \\
\text { cases) }\end{array}$ & Country & $\begin{array}{l}\text { Number } \\
\text { of cases }\end{array}$ & $\begin{array}{l}\text { Genotype } \\
\text { (number } \\
\text { of cases) }\end{array}$ & $\begin{array}{l}\text { WHO-named strain, if applicable, MeaNS Distinct Sequence ID } \\
\text { (Number of cases) }\end{array}$ \\
\hline \multirow{5}{*}{ Europe $(n=6)$} & France & 1 & B3 $(n=1)$ & $N / A, 5852(n=1)$ \\
\hline & Poland & 1 & $\mathrm{D} 8(\mathrm{n}=1)$ & MVs/Gir Somnath.IND/42.16/, $4683(n=1)$ \\
\hline & Ukraine & 1 & $\mathrm{D} 8(\mathrm{n}=1)$ & MVs/Gir Somnath.IND/42.16/, $4683(n=1)$ \\
\hline & $\begin{array}{l}\text { United } \\
\text { Kingdom }\end{array}$ & 1 & D8 $(n=1)$ & MVs/Gir Somnath.IND/42.16/, $4683(n=1)$ \\
\hline & $\begin{array}{l}\text { Multiple } \\
\text { countries }\end{array}$ & 2 & $D 8(n=1)$ & MVs/Gir Somnath.IND/42.16/, $4683(n=1)$ \\
\hline $\begin{array}{l}\text { Americas } \\
(n=3)\end{array}$ & $\begin{array}{l}\text { United } \\
\text { States of } \\
\text { America }\end{array}$ & 3 & $D 8(n=3)$ & MVs/Gir Somnath.IND/42.16/, 4683 ( $n=2) ;$ MVs/Dagon Seikkan.MMR/5.18, ID ( $n=1)$ \\
\hline \multirow{2}{*}{$\begin{array}{l}\text { South-East } \\
\text { Asian }(n=3)\end{array}$} & Bangladesh & 2 & B3 $(n=2)$ & $N / A, 5622(n=1) ; N / A, 6218(n=1)$ \\
\hline & India & 1 & $\mathrm{D} 8(\mathrm{n}=1)$ & $N / A, 5970(n=1)$ \\
\hline \multirow{4}{*}{ Other $(n=5)$} & \multirow{2}{*}{ Pakistan } & \multirow{2}{*}{2} & B3 $(n=1)$ & $N / A, 5309(n=1)$ \\
\hline & & & $\mathrm{D} 8(\mathrm{n}=1)$ & MVs/Gir Somnath.IND/42.16/, $4683(n=1)$ \\
\hline & \multirow{2}{*}{$\begin{array}{l}\text { Multiple } \\
\text { countries } \\
\text { and regions }\end{array}$} & \multirow{2}{*}{3} & B3 $(n=1)$ & MVi/Marikina City.PHL/10.18/, $5306(n=1)$ \\
\hline & & & $\mathrm{D} 8(\mathrm{n}=2)$ & MVs/Gir Somnath.IND/42.16/, $4683(n=1) ; N / A, 5601(n=1)$ \\
\hline
\end{tabular}

Abbreviations: ID, identifier; MeaNS, Measles Nucleotide Surveillance, N/A, not applicable; WHO, World Health Organization

Table 3: Summary of measles with an unknown source of exposure $(n=11)$, by earliest date of rash onset, 2019

\begin{tabular}{|c|c|c|c|c|}
\hline $\begin{array}{c}\text { Case } \\
\text { number }\end{array}$ & $\begin{array}{l}\text { Exposure } \\
\text { category }\end{array}$ & $\begin{array}{l}\text { End date } \\
\text { of the } \\
\text { epidemiologic } \\
\text { week of rash } \\
\text { onset }\end{array}$ & $\begin{array}{l}\text { Genotype } \\
\text { (WHO-named } \\
\text { strain if } \\
\text { applicable, } \\
\text { MeaNS } \\
\text { Distinct } \\
\text { Sequence ID) }\end{array}$ & Description \\
\hline 1 & $\begin{array}{l}\text { Unknown } \\
\text { (exposed } \\
\text { either in } \\
\text { Canada or } \\
\text { abroad) }\end{array}$ & February 16 & B3 (N/A, 5800) & $\begin{array}{l}\text { - The case travelled to France, where active measles outbreaks were ongoing, and } \\
\text { spent time in Canada during the exposure period } \\
\text { - Genotyping data excludes a link to other known active measles cases present in } \\
\text { the case's area of Canada during the exposure period } \\
\text { - The identified measles strain was not detected in any other case genotyped in } \\
2019 \\
\text { - The case had no documented doses of measles-containing vaccine }\end{array}$ \\
\hline 2 & $\begin{array}{l}\text { Exposed } \\
\text { in Canada, } \\
\text { not linked } \\
\text { to any } \\
\text { case }\end{array}$ & February 23 & B3 (N/A, 5654) & $\begin{array}{l}\text { - The case did not travel outside of Canada during the exposure period and had } \\
\text { no known epidemiologic links to other confirmed measles cases } \\
\text { - The identified measles strain was detected in one earlier case with travel history } \\
\text { to the Philippines } \\
\text { - The case had two documented doses of measles-containing vaccine }\end{array}$ \\
\hline 3 & $\begin{array}{l}\text { Unknown } \\
\text { (exposed } \\
\text { either in } \\
\text { Canada or } \\
\text { abroad) }\end{array}$ & March 30 & $\begin{array}{l}\text { D8 (MVs/ } \\
\text { Gir Somnath. } \\
\text { IND/42.16, 4683) }\end{array}$ & $\begin{array}{l}\text { - The case travelled to the Dominican Republic during the exposure period. At } \\
\text { the time of travel, no known active cases or outbreaks were ongoing in the } \\
\text { Dominican Republic } \\
\text { - The case was also present in an area of Canada with other active measles cases } \\
\text { during the exposure period } \\
\text { - The identified measles strain was detected in } 45 \text { other cases and has been } \\
\text { circulating globally since } 2018 \\
\text { - The case had no documented doses of measles-containing vaccine }\end{array}$ \\
\hline 4 & $\begin{array}{l}\text { Exposed } \\
\text { in Canada, } \\
\text { not linked } \\
\text { to any } \\
\text { case }\end{array}$ & March 30 & $\begin{array}{l}\text { D8 (MVs/ } \\
\text { Gir Somnath. } \\
\text { IND/42.16, 4683) }\end{array}$ & $\begin{array}{l}\text { - The case did not travel outside of Canada during the exposure period and had } \\
\text { no known epidemiologic links to other confirmed measles cases } \\
\text { - The identified measles strain was detected in } 45 \text { other cases and has been } \\
\text { circulating globally since } 2018 \\
\text { - The case had one documented dose of measles-containing vaccine }\end{array}$ \\
\hline
\end{tabular}


Table 3: Summary of measles with an unknown source of exposure $(n=11)$, by earliest date of rash onset, 2019 (continued)

\begin{tabular}{|c|c|c|c|c|}
\hline $\begin{array}{c}\text { Case } \\
\text { number }\end{array}$ & $\begin{array}{l}\text { Exposure } \\
\text { category }\end{array}$ & $\begin{array}{l}\text { End date } \\
\text { of the } \\
\text { epidemiologic } \\
\text { week of rash } \\
\text { onset }\end{array}$ & $\begin{array}{l}\text { Genotype } \\
\text { (WHO-named } \\
\text { strain if } \\
\text { applicable, } \\
\text { MeaNS } \\
\text { Distinct } \\
\text { Sequence ID)a }\end{array}$ & Description \\
\hline 5 & $\begin{array}{l}\text { Exposed } \\
\text { in Canada, } \\
\text { not linked } \\
\text { to any } \\
\text { case }\end{array}$ & March 30 & $\begin{array}{l}\text { D8 (MVs/ } \\
\text { Gir Somnath. } \\
\text { IND/42.16, 4683) }\end{array}$ & $\begin{array}{l}\text { - The case did not travel outside of Canada during the exposure period and had } \\
\text { no known epidemiologic links to other confirmed measles cases } \\
\text { - The identified measles strain was detected in } 45 \text { other cases and has been } \\
\text { circulating globally since } 2018 \\
\text { - The case had two documented doses of measles-containing vaccine }\end{array}$ \\
\hline 6 & $\begin{array}{l}\text { Exposed } \\
\text { in Canada, } \\
\text { not linked } \\
\text { to any } \\
\text { case }\end{array}$ & April 6 & $\begin{array}{l}\text { D8 (MVs/ } \\
\text { Gir Somnath. } \\
\text { IND/42.16, 4683) }\end{array}$ & $\begin{array}{l}\text { - The case did not travel outside of Canada during the exposure period } \\
\text { - Although the case had no known epidemiologic links to other confirmed measles } \\
\text { cases, they were present in an area of Canada with other active measles cases } \\
\text { during the exposure period } \\
\text { - The identified measles strain was detected in } 45 \text { other cases, including some that } \\
\text { were active in the area, and has been circulating globally since } 2018 \\
\text { - The case had no documented doses of measles-containing vaccine }\end{array}$ \\
\hline 7 & $\begin{array}{l}\text { Exposed } \\
\text { in Canada, } \\
\text { not linked } \\
\text { to any } \\
\text { case }\end{array}$ & April 6 & $\begin{array}{l}\text { D8 (MVs/ } \\
\text { Gir Somnath. } \\
\text { IND/42.16, 4683) }\end{array}$ & $\begin{array}{l}\text { - The case did not travel outside of Canada during the exposure period and had } \\
\text { no known epidemiologic links to other confirmed measles cases } \\
\text { - The identified measles strain was detected in } 45 \text { other cases and has been } \\
\text { circulating globally since } 2018 \\
\text { - The case had two documented doses of measles-containing vaccine }\end{array}$ \\
\hline 8 & $\begin{array}{l}\text { Exposed } \\
\text { in Canada, } \\
\text { not linked } \\
\text { to any } \\
\text { case }\end{array}$ & June 1 & $\begin{array}{l}\text { D8 (MVs/ } \\
\text { Gir Somnath. } \\
\text { IND/42.16, 4683) }\end{array}$ & $\begin{array}{l}\text { - The case did not travel outside of Canada during the exposure period and had } \\
\text { no known epidemiologic links to other confirmed measles cases } \\
\text { - The identified measles strain was detected in } 45 \text { other cases and has been } \\
\text { circulating globally since } 2018 \\
\text { - The case had no documented doses of measles-containing vaccine }\end{array}$ \\
\hline 9 & $\begin{array}{l}\text { Exposed } \\
\text { in Canada, } \\
\text { linked to } \\
\text { a sporadic } \\
\text { case of } \\
\text { unknown } \\
\text { origin }\end{array}$ & June 15 & $\begin{array}{l}\text { D8 (MVs/ } \\
\text { Gir Somnath. } \\
\text { IND/42.16, 4683) }\end{array}$ & $\begin{array}{l}\text { - One case was a household contact of a previous case whose source of exposure } \\
\text { was unknown. Both cases had the same measles strain } \\
\text { - The case had no documented doses of measles-containing vaccine }\end{array}$ \\
\hline 10 & $\begin{array}{l}\text { Exposed } \\
\text { in Canada, } \\
\text { not linked } \\
\text { to any } \\
\text { case }\end{array}$ & July 20 & Not determined & $\begin{array}{l}\text { - The case did not travel outside of Canada during the exposure period and had } \\
\text { no known epidemiologic links to other confirmed measles cases } \\
\text { - The case had two documented doses of measles-containing vaccine }\end{array}$ \\
\hline 11 & $\begin{array}{l}\text { Exposed } \\
\text { in Canada, } \\
\text { not linked } \\
\text { to any } \\
\text { case }\end{array}$ & September 28 & B3 (N/A, 5230) & $\begin{array}{l}\text { - The case did not travel outside of Canada during the exposure period and had } \\
\text { no known epidemiologic links to other confirmed measles cases. The case did fly } \\
\text { on multiple domestic flights during the exposure period and may have come in } \\
\text { contact with the virus in an airport } \\
\text { - The identified measles strain was not detected in any other case genotyped in } \\
2019 \\
\text { - The case had no documented doses of measles-containing vaccine }\end{array}$ \\
\hline
\end{tabular}

Abbreviations: ID, identifier; MeaNS, Measles Nucleotide Surveillance; N/A, not applicable; WHO, World Health Organization

a GenBank accession number for the listed named strain is KY120864

\section{Unknown source}

Eleven cases (10\%) were neither imported nor import-related: eight had no recent history of travel or known links to other confirmed measles cases (sporadic cases); one was linked to a sporadic case of unknown origin; and the exact source of exposure for the other two cases could not be determined (unknown source) because exposure may have occurred either in another country with known measles activity or in Canada (Table 3). These cases originated from British Columbia $(n=5)$,
Québec $(n=4)$ and Ontario $(n=2)$. Six of these cases were female and five were male. Ten of these 11 cases were genotyped; in seven cases, the genotype D8 MVs/Gir Somnath.IND/42.16/ named strain was detected, which was circulating globally in 2019. Three distinct genotype B3 strains (sequence IDs 5230, 5654 and 5800) were identified in the remaining three cases, two of which were not detected in any other measles case genotyped in 2019 (5230 and 5800) (Figure 3, Table 3). 
Figure 3: Maximum parsimony phylogenetic tree of measles $N-450$ sequences identified in Canada in 2019 ( $n=73)$ prepared using MEGA X software ${ }^{a}$

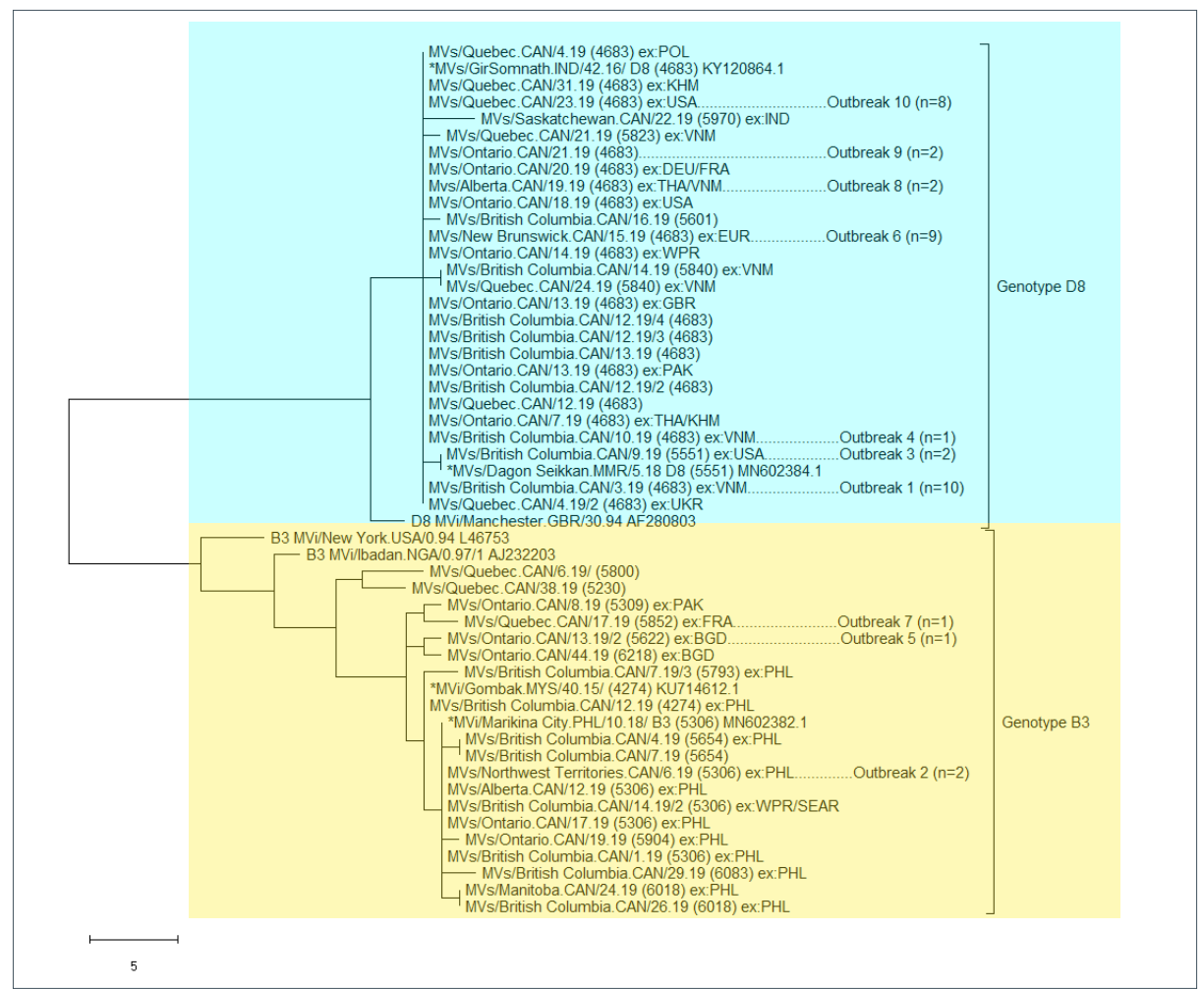

Abbreviations: ID, identifier; MeaNS, Measles Nucleotide Surveillance; WHO, World Health Organization

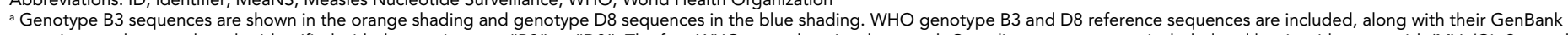

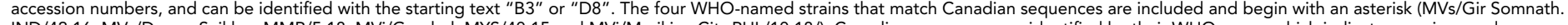
IND/42.16, MVs/Dagon Seikkan.MMR/5.18, MVi/Gombak.MYS/40.15 and MVi/Marikina City.PHL/10.18/). Canadian sequences are identified by their WHO name, which indicates province and

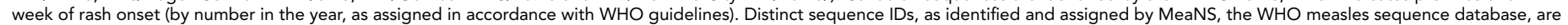

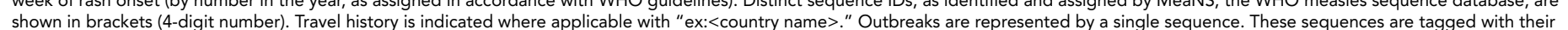

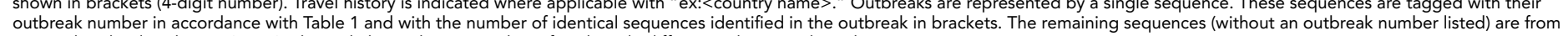
non-outbreak-related cases $(n=35)$. The scale bar indicates number of nucleotide differences between branches

\section{Outbreaks}

Ten measles outbreaks were identified for a total of 74 cases (Table 4). Seven of the 10 outbreaks were small (from 2 to 3 cases per outbreak), with limited transmission to household contacts or other close contacts of the index case. Three outbreaks were larger (from 12 to 34 cases per outbreak), with community-level transmission.
The WHO-named strain MVs/Gir Somnath.IND/42.16 was the most frequently detected in 2019. In total, 46 measles cases were identified with this strain ( $41 \%$ of all cases), and these cases were associated with six distinct outbreaks and 14 sporadic cases for a total of 20 chains of transmission. In the longest sustained outbreak associated with this strain, Outbreak 10, illness onset occurred during the week ending June 15 in the earliest case and during the week ending August 24 in the last case.

Table 4: Summary of measles outbreaks in Canada $(N=10)$, by earliest date of rash onset, 2019

\begin{tabular}{|c|c|c|c|c|c|}
\hline $\begin{array}{c}\text { Outbreak } \\
\text { number }\end{array}$ & $\begin{array}{l}\text { Province/ } \\
\text { territory }\end{array}$ & $\begin{array}{l}\text { Number } \\
\text { of cases } \\
\text { (number of } \\
\text { generations) }\end{array}$ & $\begin{array}{l}\text { End date of the } \\
\text { epidemiologic week } \\
\text { of rash onset of } \\
\text { index case }\end{array}$ & $\begin{array}{c}\text { Genotype (WHO- } \\
\text { named strain, if } \\
\text { applicable, MeaNS } \\
\text { Distinct Sequence } \\
\text { ID) }\end{array}$ & Description \\
\hline 1 & $\begin{array}{l}\text { British } \\
\text { Columbia }\end{array}$ & $13(n=5)$ & February 2 & $\begin{array}{l}\text { D8 (MVs/Gir } \\
\text { Somnath.IND/42.16, } \\
\text { 4683) }\end{array}$ & $\begin{array}{l}\text { - Three co-index cases reported travel to Viet } \mathrm{Nam} \\
\text { - } 10 \text { subsequent cases were reported later } \\
\text { - Primary exposure occurred in two schools } \\
\text { - Four of the } 13 \text { cases }(31 \%) \text { had at least one } \\
\text { documented dose of measles-containing vaccine }\end{array}$ \\
\hline 2 & $\begin{array}{l}\text { Northwest } \\
\text { Territories }\end{array}$ & $2(n=2)$ & February 16 & $\begin{array}{l}\text { B3 (MVi/Marikina } \\
\text { City.PHL/10.18, 5306) }\end{array}$ & $\begin{array}{l}\text { - The index case reported travel to the Philippines } \\
\text { - The secondary case was a contact of the index case } \\
\text { - The index case was unvaccinated } \\
\text { measles-containing vaccine prior to exposure }\end{array}$ \\
\hline
\end{tabular}


Table 4: Summary of measles outbreaks in Canada $(\mathrm{N}=10)$, by earliest date of rash onset, 2019 (continued)

\begin{tabular}{|c|c|c|c|c|c|}
\hline $\begin{array}{c}\text { Outbreak } \\
\text { number }\end{array}$ & $\begin{array}{l}\text { Province/ } \\
\text { territory }\end{array}$ & $\begin{array}{l}\text { Number } \\
\text { of cases } \\
\text { (number of } \\
\text { generations) }\end{array}$ & $\begin{array}{l}\text { End date of the } \\
\text { epidemiologic week } \\
\text { of rash onset of } \\
\text { index case }\end{array}$ & $\begin{array}{l}\text { Genotype (WHO- } \\
\text { named strain, if } \\
\text { applicable, MeaNS } \\
\text { Distinct Sequence } \\
\text { ID) }\end{array}$ & Description \\
\hline 3 & $\begin{array}{l}\text { British } \\
\text { Columbia }\end{array}$ & $2(n=2)$ & March 9 & $\begin{array}{l}\text { D8 (MVs/Dagon } \\
\text { Seikkan.MMR/5.18, } \\
\text { 5551) }\end{array}$ & $\begin{array}{l}\text { - The index case reported travel to the US } \\
\text { - The secondary case was a family contact of the index } \\
\text { case } \\
\text { - The index case was unvaccinated } \\
\text { - The secondary case had two documented doses of } \\
\text { measles-containing vaccine prior to exposure }\end{array}$ \\
\hline 4 & $\begin{array}{l}\text { British } \\
\text { Columbia }\end{array}$ & $2(n=2)$ & March 9 & $\begin{array}{l}\text { D8 (MVs/Gir } \\
\text { Somnath.IND/42.16, } \\
\text { 4683) }\end{array}$ & $\begin{array}{l}\text { - The index case reported travel to Viet Nam } \\
\text { - The secondary case was a family contact of the index } \\
\text { case } \\
\text { - The index case was unvaccinated } \\
\text { - The secondary case had one documented dose of } \\
\text { measles-containing vaccine prior to exposure }\end{array}$ \\
\hline 5 & Ontario & $2(n=2)$ & March 23 & B3 (N/A, 5622) & $\begin{array}{l}\text { - The index case reported travel to Bangladesh } \\
\text { - The secondary case was a household contact of the } \\
\text { index case } \\
\text { - The index case was unvaccinated } \\
\text { - The secondary case had one documented dose of } \\
\text { measles-containing vaccine }\end{array}$ \\
\hline 6 & $\begin{array}{l}\text { New } \\
\text { Brunswick }\end{array}$ & $12(n=3)$ & April 27 & $\begin{array}{l}\text { D8 (MVs/Gir } \\
\text { Somnath.IND/42.16, } \\
\text { 4683) }\end{array}$ & $\begin{array}{l}\text { - The index case reported travel to various countries in } \\
\text { - Turope } \\
\text { - } \text { index case } \\
\text { - } 10 \text { tertiary cases followed after exposures in a school } \\
\text { and in the community } \\
\text { - The index case was unvaccinated } \\
\text { - } 10 \text { of the } 11 \text { subsequent cases had at least one } \\
\text { documented dose of measles-containing vaccine } \\
\text { - Nine of the cases ( } 75 \% \text { ) in this outbreak had two } \\
\text { documented doses of measles-containing vaccine }\end{array}$ \\
\hline 7 & Québec & $3(n=2)$ & May 4 & B3 (N/A, 5852) & $\begin{array}{l}\text { - The index case reported travel to France } \\
\text { - Two secondary cases were contacts of the index case } \\
\text { - One of the secondary cases was unvaccinated, while } \\
\text { the other had two documented doses of measles- } \\
\text { containing vaccine }\end{array}$ \\
\hline 8 & Alberta & $2(n=2)$ & May 18 & $\begin{array}{l}\text { D8 (MVs/Gir } \\
\text { Somnath.IND/42.16, } \\
\text { 4683) }\end{array}$ & $\begin{array}{l}\text { - The index case reported travel to Viet Nam and } \\
\text { Thailand } \\
\text { - The secondary case was a workplace contact } \\
\text { - Neither case had any documented doses of measles- } \\
\text { containing vaccine }\end{array}$ \\
\hline 9 & Ontario & $2(n=2)$ & June 1 & $\begin{array}{l}\text { D8 (MVs/Gir } \\
\text { Somnath.IND/42.16, } \\
\text { 4683) }\end{array}$ & $\begin{array}{l}\text { - The index case did not report travel outside of Canada } \\
\text { during the exposure period } \\
\text { - The secondary case was a household contact } \\
\text { - Neither case had any documented doses of measles- } \\
\text { containing vaccine }\end{array}$ \\
\hline 10 & Québec & 34 (unknown) & June 15 & $\begin{array}{l}\text { D8 (MVs/Gir } \\
\text { Somnath.IND/42.16, } \\
\text { 4683) }\end{array}$ & $\begin{array}{l}\text { - The index case reported travel to an area of } \\
\text { heightened measles activity in the US } \\
\text { - Several generations of transmission were linked to a } \\
\text { shopping mall and a non-vaccinating community in } \\
\text { the Montréal area } \\
\text { - } 32 \text { cases, including the index case, were unvaccinated } \\
\text { - Two cases had at least one documented dose of a } \\
\text { measles-containing vaccine }\end{array}$ \\
\hline
\end{tabular}




\section{Verification of measles elimination through national and international goals and targets}

The data in this report are provided as evidence in support of the ongoing verification of measles elimination in Canada, for which the PAHO has set out four essential criteria (9). Based on the information available, Canada met or partially met three of the four criteria in 2019 (Table 5).

Table 5: Pan American Health Organization essential criteria for the verification of measles elimination

\begin{tabular}{|c|c|}
\hline Criterion & Indicator \\
\hline $\begin{array}{l}\text { Verify the interruption of } \\
\text { endemic measles cases } \\
\text { for a period of at least } 3 \\
\text { years from the last known } \\
\text { endemic case, in the } \\
\text { presence of high-quality } \\
\text { surveillance }\end{array}$ & $\begin{array}{l}\text { Criterion met } \\
\text { Canada achieved measles elimination } \\
\text { status in 1998. Since then, molecular } \\
\text { and epidemiologic data continue to } \\
\text { demonstrate that no viral strain has } \\
\text { circulated for a period of } \geq 1 \text { year (Figure } 4) \\
(4,16-19)\end{array}$ \\
\hline $\begin{array}{l}\text { Maintain high-quality } \\
\text { surveillance sensitive } \\
\text { enough to detect } \\
\text { imported and import- } \\
\text { related cases }\end{array}$ & $\begin{array}{l}\text { Criterion partially met } \\
\text { In Canada, national measles surveillance } \\
\text { conducted through CMRSS consists of } \\
\text { confirmed case surveillance and does not } \\
\text { capture the number of clinical or suspect } \\
\text { cases investigated, which are investigated } \\
\text { at the provincial and territorial levels. } \\
\text { However, based on data obtained by } \\
\text { the Measles and Rubella Surveillance } \\
\text { Pilot Project (which does not include all } \\
\text { provinces and territories), the national rate } \\
\text { of suspected case investigations has been } \\
\text { previously estimated to be between } 12 \\
\text { and } 19 \text { per } 100,000 \text { population (17). } \\
\text { Although the indicator cannot be } \\
\text { met, the criterion has been met as the } \\
\text { epidemiologic and laboratory evidence } \\
\text { provided in this report indicates that } \\
\text { Canada's measles surveillance capacity is } \\
\text { sufficiently sensitive to detect imported } \\
\text { and import-related cases and conduct case } \\
\text { investigations }\end{array}$ \\
\hline $\begin{array}{l}\text { Verify the absence of } \\
\text { endemic measles virus } \\
\text { strains through viral } \\
\text { surveillance }\end{array}$ & $\begin{array}{l}\text { Criterion met } \\
\text { Genotype information was available for } \\
10 / 10 \text { of outbreaks reported in } 2019 . \\
\text { Genotype information was also available } \\
\text { for } 90 \% \text { of non-outbreak-related measles } \\
\text { cases ( } 35 \text { genotyped of } 39 \text { cases) }\end{array}$ \\
\hline $\begin{array}{l}\text { Verify adequate } \\
\text { immunization in the } \\
\text { population }\end{array}$ & $\begin{array}{l}\text { Criterion not met } \\
\text { Canada currently measures (biennially) } \\
\text { measles vaccination coverage rates at } 2 \\
\text { and } 7 \text { years of age, and therefore is unable } \\
\text { to assess measles vaccination coverage for } \\
\text { all ages } 1-40 \text { years. The } 2017 \text { childhood } \\
\text { National Immunization Coverage Survey } \\
\text { estimated first dose measles-containing } \\
\text { vaccine coverage in two year olds to be } \\
90 \% \text {, and two-dose measles-containing } \\
\text { vaccine coverage in seven year olds to be } \\
86 \% \text { (5) }\end{array}$ \\
\hline
\end{tabular}

Abbreviation: CMRSS, Canadian Measles and Rubella Surveillance System

\section{Discussion}

There were 113 confirmed cases of measles reported in Canada in 2019, the majority of which were imported or import-related (90\%) and unvaccinated against measles (71\%). This is higher than the median number of cases reported from 1998 to 2018 (median of 32 cases per year), and coincides with a trend of increasing rates of measles globally since 2017 (2,20-22). The United States (US) had the greatest number of measles cases since 1992 in 2019 . Over $73 \%$ of cases in the US were linked to outbreaks in New York, and the majority of the cases in these outbreaks were not vaccinated against measles (23). These US outbreaks had a direct impact on measles rates in Canada, with the largest Canadian outbreak of 2019 epidemiologically linked to a large outbreak in the US. Other large outbreaks in Canada were caused by unvaccinated travellers to Viet Nam and Europe, where outbreaks were also occurring in 2019. These outbreaks underscore the ongoing risk that any international travel places on the spread of measles in Canada, and validates PHAC's 2019 broadening of its travel health notice for measles exposure risk to any international travel, and not only to certain areas (24).

Globally, only four of the 24 recognized measles genotypes continue to be detected, genotypes B3, D4, D8 and H1, as a result of elimination efforts (4), and only genotypes B3 and D8 were detected in confirmed measles cases in Canada in 2019. The genotype classification system captures viruses with similar yet distinct genetic (N-450) sequences, and for effective molecular epidemiology, additional granularity is required. The WHO global measles rubella laboratory network developed a system of "named strains" that are defined in the MeaNS database and represent a lineage, a precisely defined virus strain with a specific $\mathrm{N}-450$ sequence, that has been frequently detected within a 2-year period in multiple countries (11). In addition, the MeaNS database assigns a 4-digit identifier to all distinct or unique $\mathrm{N}-450$ sequences within the database. All sequences obtained from cases of measles with the same $\mathrm{N}-450$ sequence will share the same distinct sequence ID. In this way, all possible genetic sequences of reported measles cases can be tracked with their distinct sequence ID and some will also be designated as belonging to a named strain lineage, representing those with broader circulation. In 2019, 19 distinct sequence IDs, including four named strains, were identified in the 73 confirmed cases of measles that were genotyped.

The WHO-named strain MVs/Gir Somnath.IND/42.16 was the only strain detected in 2019 that was also detected in a handful of cases in 2018 (16). This strain has been circulating globally since 2018, based on submissions to the MeaNS database, as reflected in the number of cases with travel history associated with this strain both in 2018 and 2019 (Figure 4). In 2018 to 2019, 51 measles cases were identified with this strain and these cases were associated with seven distinct outbreaks and 17 sporadic cases for a total of 24 chains of transmission. The time between illness onset in the first and last cases in the longest 
sustained outbreak associated with this strain was 70 days, which is far short of the 12 months of ongoing transmission that would signal endemic circulation. The detection of this strain in a large number of chains of transmission over an extended time demonstrates the value of integrating laboratory and epidemiologic data and necessitates the adoption of extended genotyping methods.

Both in Canada and abroad, maintaining high vaccination coverage rate with measles-containing vaccine requires a sustained public health effort and is an essential component of a strategy for achieving and maintaining measles elimination. As in previous years, the large majority of measles cases were unvaccinated, highlighting the importance of adhering to vaccination guidelines $(16,17,25-27)$. Only one in five measles cases in $\mathbf{2 0 1 9}$ had received two doses of measles vaccination, including five cases who were aged younger than one year and not yet eligible to receive the first routine dose of measlescontaining vaccine under the routine vaccination schedule (25).

The age distribution of measles cases reported in 2019 was similar to that seen in previous years, with younger age groups affected to a higher degree than older age groups (16-18). Of note, over half of the measles cases in the 15-24 year age group had received two doses of measles-containing vaccine. The majority $(n=7)$ of the fully vaccinated cases from this age

Figure 4: Number of measles cases with genotype D8, WHO-named strain MVs/Gir Somnath.IND/42.16 detected in 2018 and 2019 ( $n=51)$, by epidemiologic week of rash onset, chain of transmission status and source of exposure, Canada

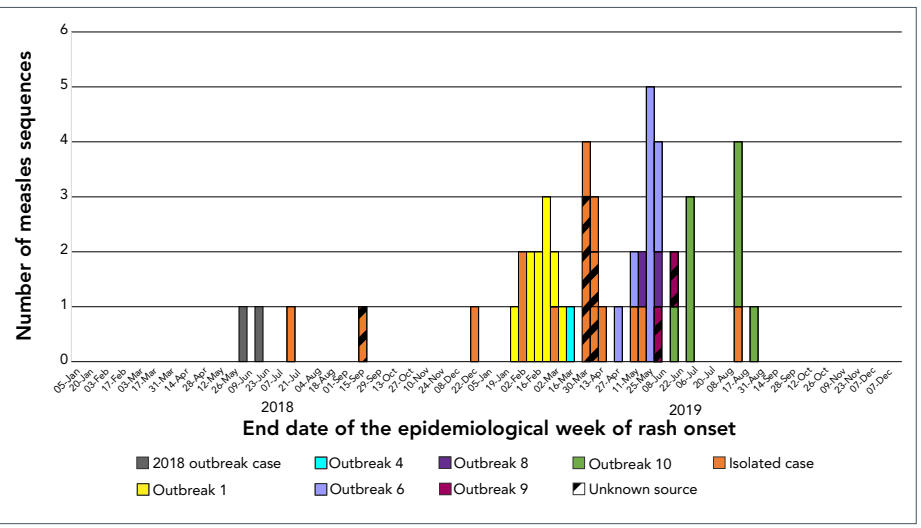

Abbreviation: WHO, World Health Organization

a Chains of transmission (outbreak or sporadic case) are identified by colour with 2019 outbreaks numbered as per Table 4. Solid bars reflect cases with known source of exposure. Bars with diagonal stipes indicate cases with unknown source

group were related to a large outbreak in a secondary school in which many students were exposed. Given the large number of individuals exposed in this outbreak, some breakthrough cases, or cases that developed measles despite being fully vaccinated, would be expected even with high vaccine coverage. In addition, seroepidemiology conducted in the province of Ontario has found that this age group may have waning immunity to measles (28). Breakthrough cases may have either failed to develop an appropriate immune response; their immunity may have waned to non-protective levels by time of exposure; or the vaccine they were given may have been stored, handled or administered improperly $(29,30)$.

Based on the information available, Canada met or partially met three of the four PAHO essential criteria for the verification of measles elimination in 2019. Canada falls short of the criterion regarding measles-containing vaccine coverage. Canada currently measures (biennially) measles vaccination coverage rates at 2 and 7 years of age, and therefore is unable to assess measles vaccination coverage for all ages between 1 and 40 years, as set out in the PAHO elimination framework. The 2017 estimate for two year olds receiving measles-containing vaccine is $90 \%$ and for seven year olds receiving the second dose of measles-containing vaccine is $86 \%$, below the $\mathrm{PAHO}$ indicator of $95 \%$ (5). This estimate is derived from a survey that collected data from parent-held vaccination records, in which some information may be incomplete, erroneous or missing altogether. As vaccine doses with missing or invalid date are not counted in the calculation of coverage, the survey most likely underestimates coverage.

\section{Strengths and limitations}

This report has several limitations that bear consideration. Only measles cases that interact with the Canadian health system are captured in enhanced measles surveillance, and therefore cases with mild symptoms or visitors to Canada who do not seek health care may not be detected. Other federal or provincial surveillance systems may use case attribution methods that differ from CMRSS, which can cause discrepancies in annual case counts (31). Information on mortality and detailed information on morbidity (e.g. length of hospitalization, sequelae) are not currently captured by CMRSS, limiting the ability to completely describe the burden of illness due to measles. However, despite these limitations, this report serves to provide a detailed picture of measles in Canada in 2019 through an integrated analysis of both laboratory and epidemiologic case data for all reported cases.

\section{Conclusion}

The occurrence of measles cases and subsequent measles outbreaks in Canada in 2019, which were largely due to measles importations, underscore the importance of continued enhanced measles surveillance and efforts to increase vaccine uptake across the country. Although importation of measles and areas of low vaccination coverage continue to challenge Canada's elimination status, the laboratory and epidemiologic evidence provided by this report indicates that endemic transmission of the measles virus has not been re-established in Canada. 


\section{Authors' statement}

CC - Methodology, software, formal analysis, investigation, data curation, writing-original draft, writing-review and editing, visualization FRD - Conceptualization, methodology, formal analysis, writingoriginal draft, writing-review and editing, project administration $\mathrm{JH}$ - Methodology, validation, investigation, data curation, writing-original draft, writing-review and editing SS - Conceptualization, methodology, writing-review and editing, project administration

\section{Competing interests}

None.

\section{Acknowledgements}

The authors gratefully acknowledge the continued cooperation and efforts of provincial and territorial surveillance and laboratory partners in providing and validating data captured by Canadian Measles and Rubella Surveillance System (CMRSS) and referring specimens for molecular surveillance (genotyping) and for their review of the report content. The authors would like to thank Dr. C Dickson for her valuable contributions to the report.

\section{Funding}

This work was supported by the Public Health Agency of Canada.

\section{References}

1. World Health Organization (WHO). Measles. Geneva (CH): WHO; (accessed 2020-02). http://www.who.int/news-room/ fact-sheets/detail/measles
2. Patel MK, Dumolard L, Nedelec $Y$, Sodha SV, Steulet C, Gacic-Dobo M, Kretsinger K, McFarland J, Rota PA, Goodson JL. Progress toward regional measles eliminationworldwide, 2000-2018. MMWR Morb Mortal Wkly Rep 2019;68(48):1105-11. DOI PubMed

3. King A, Varughese P, De Serres G, Tipples GA, Waters J; Working Group on Measles Elimination. Measles elimination in Canada. J Infect Dis 2004;189 Suppl 1:S236-42. DOI PubMed

4. Public Health Agency of Canada. Elimination of measles rubella and congenital rubella syndrome in Canada: documentation and verification report: executive summary. Ottawa (ON): Government of Canada; 2013-04 (accessed 2020-02). https://www.canada.ca/en/public-health/ services/immunization/vaccine-preventable-diseases/ elimination-measles-rubella-congenital-rubella-syndrom e-canada-documentation-verification-report.html

5. Public Health Agency of Canada. Vaccine coverage in Canadian children: results from the 2017 Childhood National Immunization Coverage Survey (cNICS). Ottawa (ON): Government of Canada; 2019 (accessed 2020-03). https:// www.canada.ca/en/public-health/services/publications/ healthy-living/2017-vaccine-uptake-canadian-children-survey. html

6. Public Health Agency of Canada. Canadian vaccination coverage goals and vaccine preventable disease reduction targets by 2025; Vaccine preventable disease reduction targets by 2025; Diseases under elimination: Maintain elimination status. Ottawa (ON): Government of Canada; 2020 (accessed 2020-01). https://www.canada. ca/en/public-health/services/immunization-vaccinepriorities/national-immunization-strategy/ vaccination-coverage-goals-vaccine-preventable-disea ses-reduction-targets-2025.html\#2.1

7. Public Health Agency of Canada. Case definitions for diseases under national surveillance: results of provincial/territorial (P/T) consultation process. Can Commun Dis Rep 2009;35-Suppl 2:71-2.

https://www.canada.ca/content/dam/phac-aspc/migration/ phac-aspc/publicat/ccdr-rmtc/09pdf/35s2-eng.pdf

8. Public Health Agency of Canada. Canadian measles/ rubella surveillance system. Ottawa (ON): Government of Canada; (accessed 2020-02). https://www.canada.ca/en/ public-health/services/surveillance.html\#a5

9. Pan-American Health Organization. Plan of action. Documentation and verification of measles, rubella and congenital rubella syndrome elimination in the region of the Americas. Washington (DC): PAHO; 2010. https://www. paho.org/immunization/toolkit/resources/paho-publication/ PoA-Documentation-Verification-MRCRS-Elimination-e.pdf

10. World Health Organization. Expanded Programme on Immunization (EPI). Standardization of the nomenclature for describing the genetic characteristics of wild-type measles viruses. Wkly Epidemiol Rec 1998;73(35):265-9. PubMed

11. World Health Organization. Genetic diversity of wild-type measles viruses and the global measles nucleotide surveillance database (MeaNS). Wkly Epidemiol Rec 2015;90(30):373-80. PubMed 
12. Kumar S, Stecher G, Li M, Knyaz C, Tamura K. MEGA X: molecular Evolutionary Genetics Analysis across computing platforms. Mol Biol Evol 2018;35(6):1547-9. DOI PubMed

13. Rota PA, Brown K, Mankertz A, Santibanez S, Shulga S, Muller CP, Hübschen JM, Siqueira M, Beirnes J, Ahmed H, Triki H, Al-Busaidy S, Dosseh A, Byabamazima C, Smit S, Akoua-Koffi C, Bwogi J, Bukenya H, Wairagkar N, Ramamurty N, Incomserb P, Pattamadilok S, Jee Y, Lim W, Xu W, Komase K, Takeda M, Tran T, Castillo-Solorzano C, Chenoweth P, Brown D, Mulders MN, Bellini WJ, Featherstone D. Global distribution of measles genotypes and measles molecular epidemiology. J Infect Dis 2011;204 Suppl 1:S514-23. DOI PubMed

14. Measles and Rubella Elimination Working Group (MREWG), Public Health Agency of Canada. Guidelines for the prevention and control of measles outbreaks in Canada. An Advisory Committee Statement (ACS) Measles and Rubella Elimination Working Group (MREWG). Can Commun Dis Rep 2013;39(ACS-3):1-52. DOI

15. World Health Organization (WHO). Measles and rubella surveillance Data. Geneva (CH): WHO; (accessed 2020-02). https://www.who.int/immunization/monitoring_surveillance/ burden/vpd/surveillance_type/active/measles_monthlydata/ en/

16. Coulby C, Domingo FR, Hiebert J, MacDonald D. Measles surveillance in Canada: 2018. Can Commun Dis Rep 2020;46(4):77-83. DOI PubMed

17. Sherrard L, Hiebert J, Squires S. Measles surveillance in Canada: trends for 2014. Can Commun Dis Rep 2015;41(7):157-68. DOI PubMed

18. Public Health Agency of Canada. Measles surveillance in Canada: 2017. Ottawa (ON): Government of Canada; 2018 (accessed 2020-03). https://www.canada.ca/en/ public-health/services/publications/diseases-conditions/ measles-surveillance-canada-2017.html

19. Public Health Agency of Canada. Sustainability of Measles, Rubella and Congenital Rubella Syndrome (CRS) Elimination. Country template for the update of country reports (PAHO/ WHO). Ottawa (ON): Government of Canada; 2016-04

20. World Health Organization. Feasibility assessment of measles and rubella eradication. Geneva (CH): WHO; 2019 (accessed 2020-03). https://www.who.int/immunization/ sage/meetings/2019/october/3_Feasibility_Assessment_of_ Measles_and_Rubella_Eradication_updatedSAGE.pdf
21. Dabbagh A, Laws RL, Steulet C, Dumolard L, Mulders MN, Kretsinger K, Alexander JP, Rota PA, Goodson JL. Progress toward regional measles eliminationworldwide, 2000-2017. MMWR Morb Mortal Wkly Rep 2018;67(47):1323-9. DOl PubMed

22. Public Health Agency of Canada. Vaccine preventable disease: surveillance report to December 31, 2017. Ottawa (ON): Government of Canada; 2020 (accessed 2020-10). https://www.canada.ca/en/public-health/services/ publications/vaccines-immunization/vaccine-preventabl e-disease-surveillance-report-december-31-2017.html

23. United States Centre for Disease Control and Prevention. Measles (Rubeola): measles cases and outbreaks. Atlanta (GA): U.S. Department of Health \& Human Services; 2019 (accessed 2020-02). https://www.cdc.gov/measles/ cases-outbreaks.html

24. Public Health Agency of Canada. Global measles notice. Ottawa (ON): Government of Canada; 2019 (accessed 2020-05). https://travel.gc.ca/travelling/health-safety/ travel-health-notices/203

25. Provincial and territorial routine and catch-up vaccination schedule for infants and children in Canada. Ottawa (ON): Government of Canada; 2018 (accessed 202001). https://www.canada.ca/en/public-health/services/ provincial-territorial-immunization-information/ provincial-territorial-routine-vaccination-programs-infantschildren.html

26. Measles vaccine: Canadian immunization guide: Table 1: Criteria for measles immunity. Ottawa (ON): Government of Canada; 2018 (accessed 2020-01). https://www.canada. ca/en/public-health/services/publications/healthy-living/ canadian-immunization-guide-part-4-active-vaccines/page12-measles-vaccine.html\#p4c11t1

27. Immunization of travellers: Canadian immunization guide. Ottawa (ON): Government of Canada; 2017 (accessed 2020-02). https://www.canada.ca/en/ public-health/services/publications/healthy-living/ canadian-immunization-guide-part-3-vaccination-specificpopulations/page-9-immunization-travellers.html 
28. Bolotin S, Severini A, Hatchette T, McLachlan E, Savage R, Hughes SL, Wang J, Deeks SL, Wilson S, Brisson M, Halperin SA, Gubbay J, Mazzulli T, Serhir B, Ward BJ, Crowcroft N. Assessment of population immunity to measles in Ontario, Canada: a Canadian Immunization Research Network (CIRN) study. Hum Vaccin Immunother 2019;15(12):2856-64. DOI PubMed

29. Breakwell L, Moturi E, Helgenberger L, Gopalani SV, Hales C, Lam E, Sharapov U, Larzelere M, Johnson E, Masao C, Setik E, Barrow L, Dolan S, Chen TH, Patel M, Rota P, Hickman C, Bellini W, Seward J, Wallace G, Papania M. Measles outbreak associated with vaccine failure in adults - Federated States of Micronesia, February-August 2014. MMWR Morb Mortal Wkly Rep 2015;64(38):1088-92. DOI PubMed
30. Hinman AR, Orenstein WA, Mortimer EA Jr. When, where, and how do immunizations fail? Ann Epidemiol 1992;2(6):805-12. DOI PubMed

31. Public Health Agency of Canada. Case definitions for communicable diseases under national surveillance: results of provincial/territorial $(\mathrm{P} / \mathrm{T})$ consultation process. Can Commun Dis Rep 2009;35 S2:1-123. https://www.canada.ca/en/public-health/services/ reports-publications/canada-communicable-disease-reportccdr/monthly-issue/2009-35/definitions-communicabl e-diseases-national-surveillance.html

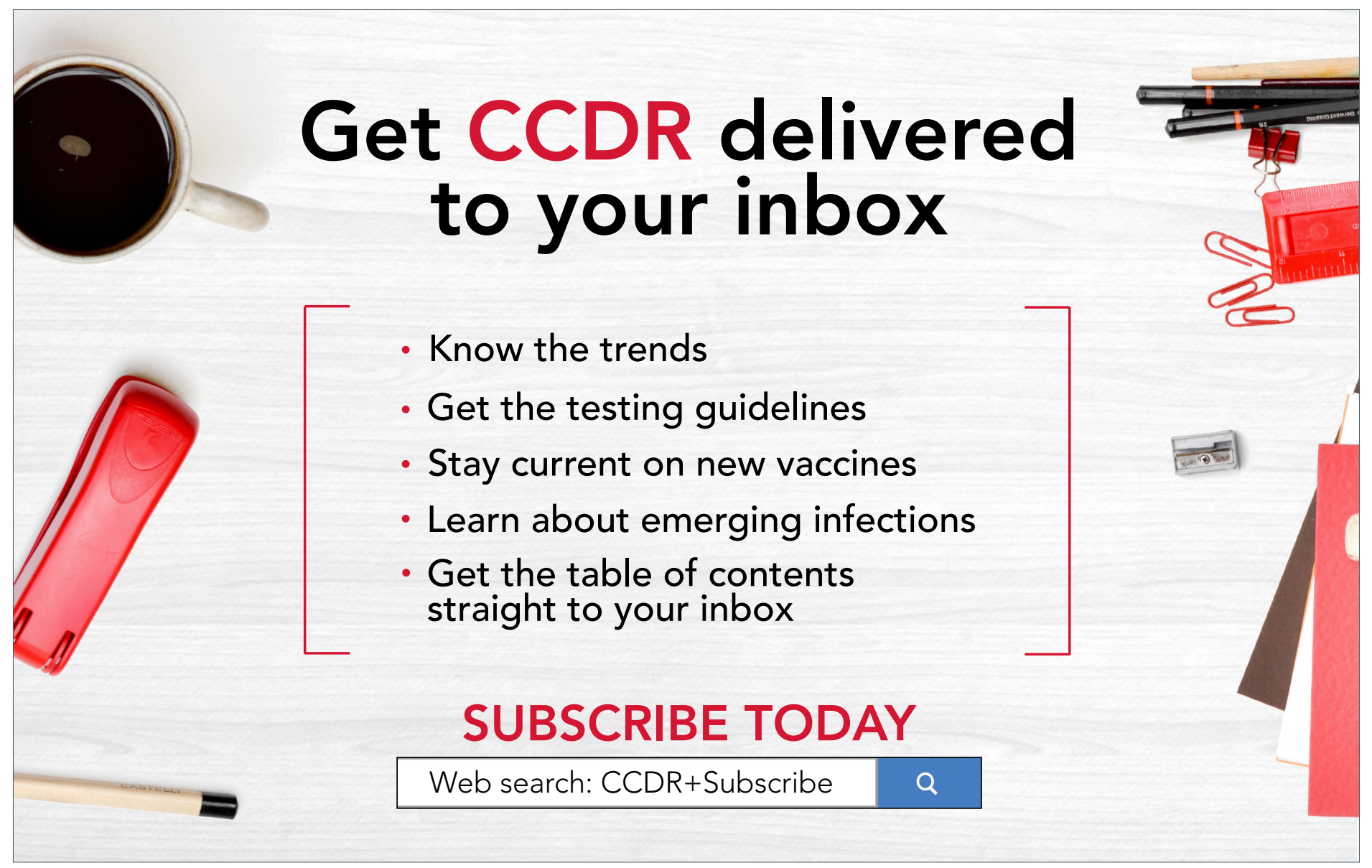

